\title{
A Self-Aggregating Deep Cavitand Acts as a Fluorescence Displacement Sensor for Lysine Methylation
}

Yang Liu, Lizeth Perez, Magi Mettry, Connor J. Easley, Richard J. Hooley* and Wenwan Zhong*

Department of Chemistry, University of California, Riverside, CA 92521, United States

richard.hooley@ucr.edu; wenwan.zhong@ucr.edu

\section{Supporting Information}

\section{General Information}

${ }^{1} \mathrm{H}$ and ${ }^{13} \mathrm{C}$ NMR spectra were recorded on a Varian Inova $400 \mathrm{MHz}$ NMR spectrometer and processed using MestReNova by Mestrelab Research S.L. Proton $\left({ }^{1} \mathrm{H}\right)$ chemical shifts are reported in parts per million $(\delta)$ with respect to tetramethylsilane (TMS, $\delta=0$ ), and referenced internally with respect to the protio solvent impurity. Deuterated NMR solvents were obtained from Cambridge Isotope Laboratories, Inc., Andover, MA, and used without further purification. Mass spectra were recorded by electrospray ionization on an LTQ-XL linear ion trap mass spectrometer (Thermo Scientific, San Jose, CA). A P/ACE PA800 capillary electrophoresis system equipped with a diode array detector (Beckman Coulter, Fullerton, CA) was used for all CE experiments. $\mathrm{CE}$ solutions were prepared in the deionized water purified by the Milli.Q water purification system (Billerica, MA). Molecular modeling (semi-empirical calculations) was performed using the AM1 force field using SPARTAN. Cavitand 1 was synthesized according to literature procedures. ${ }^{1}$ Trimethylammonium guest 2 was synthesized according to literature procedures. ${ }^{2}$ Solvents were dried through a commercial solvent purification system (Pure Process Technologies, Inc.). 
High purity (>95\%) Histone H3 (1-21) peptide (H-ART KQT ARK STG GKA PRK QLA -OH) with different methylation (Non-, Mono-, Di- and Tri-) on Lysine 9 (K9) was purchased from Anaspec and used as received. Jumonji domain containing 2E (JMJD2E) and its inhibitor 2,4dicarboxypyridine(2,4-PDCA) were purchased from Cayman Chemical (Ann Arbor, MI). All other materials, including fluorescein, L-Ascorbic acid (ascorbate), ammonium ferrous sulfate, 2oxoglutarate (2-OG) and human serum albumin (HSA), were purchased form Sigma Aldrich (St.Louis, MO), Fisher Scientific (Fairlawn, NJ), or TCI (Tokyo, Japan) and were used as received.

\section{Experimental Procedures}

\section{Synthesis of Fluorescein Guests:}

Fluorescein isothiocyanate $(25 \mathrm{mg}, 0.64 \mathrm{mmol})$ was added to a $10 \mathrm{~mL}$ round bottom flask with stir bar. The system was purged and placed under nitrogen followed by addition of dry THF (1 $\mathrm{mL}$ ). The corresponding amine (either N-methylethylenediamine or unsym-N,Ndimethylethylene-diamine was added $(0.64 \mathrm{mmol})$ and the reaction was stirred at room temperature overnight. The reaction mixture was filtered and the product collected as a bright orange solid.

Monomethylated Guest 4: H NMR (500 MHz, $\left.\mathrm{D}_{2} \mathrm{O}\right): \delta 7.55(\mathrm{~s}, 2 \mathrm{H}), 7.40(\mathrm{~d}, J=8.0 \mathrm{~Hz}, 2 \mathrm{H})$,<smiles>CNCCNC(=S)Nc1ccc(C2c3ccc(O)cc3Oc3cc(O)ccc32)c(C(=O)O)c1</smiles>
$7.15(\mathrm{~d}, J=8.9 \mathrm{~Hz}, 2 \mathrm{H}), 6.93(\mathrm{~d}, J=8.0 \mathrm{~Hz}, 1 \mathrm{H}), 6.62(\mathrm{dd}, J=8.9,2.6$ $\mathrm{Hz}, 2 \mathrm{H}), 6.54(\mathrm{~d}, J=2.6 \mathrm{~Hz}, 2 \mathrm{H}), 4.16(\mathrm{~s}, 1 \mathrm{H}), 3.76(\mathrm{~s}, 2 \mathrm{H}), 3.35(\mathrm{t}$, $2 \mathrm{H}), 3.11(\mathrm{~s}, 3 \mathrm{H}), 3.0(\mathrm{t}, 2 \mathrm{H}) .{ }^{13} \mathrm{C} \mathrm{NMR}\left(125 \mathrm{MHz}, \mathrm{D}_{2} \mathrm{O}\right): \delta 180.7$, $180.4,173.1,158.4,140.4,131.2,130.1,129.4,122.9,112.2,103.6$, 67.8, 66.5, 49.6, 37.5, 37.1, 33.2. ESI $\mathrm{MH}^{+} \mathrm{m} / z$ expected: 465.14, found: $\mathrm{M}^{+}=464.1296$.

Dimethylated Guest 3: ${ }^{1} \mathrm{H}$ NMR $\left(700 \mathrm{MHz}, \mathrm{DMSO}-d_{6}\right): \delta 8.23(\mathrm{~s}, 2 \mathrm{H}), 7.75(\mathrm{~d}, J=8.0 \mathrm{~Hz}$,<smiles>CN(C)CCNC(=S)Nc1ccc(C2c3ccc(O)cc3Oc3cc(O)ccc32)c(C(=O)O)c1</smiles>
2H), $7.09(\mathrm{~d}, J=8.0 \mathrm{~Hz}, 2 \mathrm{H}), 6.67(\mathrm{~d}, J=8.9 \mathrm{~Hz}, 2 \mathrm{H}), 6.60(\mathrm{~d}, J=2.1$ $\mathrm{Hz}, 2 \mathrm{H}), 6.44(\mathrm{dd}, J=8.9,2.1 \mathrm{~Hz}, 2 \mathrm{H}), 5.75(\mathrm{~s}, 1 \mathrm{H}), 3.60(\mathrm{~m}, 2 \mathrm{H}), 3.50$ (s, 2H), 2.66 (m, 2H), 2.19 (s, 6H). ${ }^{13} \mathrm{C}$ NMR (175 MHz, DMSO-d6): $\delta$ 180.22 , 168.78, 166.73, 158.65, 153.88, 152.10, 129.51, 128.86, 125.96, $116.18,112.38,110.48,109.51,102.34,66.98,59.49,57.12,45.12$. ESI $\mathrm{MH}^{+} m / z$ expected: 479.15 , found: $\mathrm{M}^{+}=478.1435$. 


\section{Measurement of Fluorescence Quenching and Peptide Displacement:}

In a typical quenching assay, $10 \mu \mathrm{L}$ of the fluorescent guest $(\mathbf{2}, \mathbf{3}$, or $\mathbf{4})(30 \mu \mathrm{M}), 10 \mu \mathrm{L}$ of the cavitand $1(200 \mu \mathrm{M})$, and $80 \mu \mathrm{L}$ of the $1 \times \mathrm{PBS}(10 \mathrm{mM}$ phosphate at $\mathrm{pH} 7.4$ with $150 \mathrm{mM} \mathrm{NaCl})$ were mixed in the 96-well plate, and incubated with mild shaking for 10 minutes. Followed, fluorescence was recorded in a Perkin Elmer Wallac 1420 Victor 2 Microplate Reader (PerkinElmer, Inc., Waltham, MA) with the EX/EM wavelengths at 485/535 nm. To observe the effect of fluorescence recovery induced by various histone peptides or the interfering peptides, 10 $\mu \mathrm{L}$ of the guest molecule $(30 \mu \mathrm{M})$ was mixed with $10 \mu \mathrm{L}$ of cavitand $(200 \mu \mathrm{M})$ and $70 \mu \mathrm{L}$ of PBS and incubated for 10 minutes; then $10 \mu \mathrm{L}$ of the peptide solution was added to obtain the final peptide concentration in the range of 0 to $44 \mu \mathrm{M}$. Fluorescence reading was taken after 20 minutes.

One of the interfering samples tested was the digest prepared from HSA using the following procedure. First, $200 \mu \mathrm{L}$ HSA $(2 \mathrm{mg} / \mathrm{mL})$ was denatured at $100{ }^{\circ} \mathrm{C}$. Followed, $5 \mu \mathrm{L}$ of DTT (Dithiothreitol, $200 \mathrm{mM}$ ), $20 \mu \mathrm{L}$ of IAA $(200 \mathrm{mM})$, and $20 \mu \mathrm{L}$ of DTT (200 mM) were added sequentially and an incubation step of 30 minutes was applied after the addition of each reagent. At last, Trypsin equivalent to $2 \%$ of the protein mass was added to initiate the overnight incubation at $37{ }^{\circ} \mathrm{C}$. The other interfering molecules tested were the lysate prepared from the Mouse Raw 264.7 macrophages. The cells were treated with the M-PERTM Mammalian Protein Extraction

Reagent. The cell debris was removed by centrifugation at $14,000 \times \mathrm{g}$ for 5 minutes, and the supernatant was collected and used after quantifying the protein concentration by the Pierce BCA Protein Assay kit (Thermo Fisher).

To investigate the effect on peptide displacement from salt concentrations, the peptide displacement assay was carried out in $10 \mathrm{mM}$ phosphate buffer $(\mathrm{pH}=7.4)$ supplied with sodium chloride concentrations at $0,150,300,600$, and $1200 \mathrm{mM}$. The impact from the type of anions was studied using the sodium salt of citrate, sulfate, chloride, or iodide at the concentration of $150 \mathrm{mM}$, with the $\mathrm{pH}$ adjusted to 7.4 using sodium hydroxide.

\section{Measurement of Enzyme Activity}

Demethylation reaction mixture contained $1 \mathrm{mM}$ ascorbic acid, $10 \mu \mathrm{M} \mathrm{Fe}^{2+}$ (ammonium ferrous sulfate), $50 \mu \mathrm{M} 2-\mathrm{OG}, 20 \mu \mathrm{M} \mathrm{H} 3 \mathrm{~K}_{9} \mathrm{Me}_{3}$, and the demethylase, JMJD2E, at various concentrations. At different reaction duration, the mixture was heated in boiling water for 5 minutes to denature the enzyme and terminate the reaction. Then $50 \mu \mathrm{L}$ of the reaction mixture at room temperature 
was mixed with $50 \mu \mathrm{L}$ of the sensor solution that contained $40 \mu \mathrm{M}$ cavitand 1 and $6 \mu \mathrm{M}$ guest $\mathbf{2}$, and incubated for 20 mins, prior to fluorescence measurement in the plate reader. Measurement of the $\mathrm{IC}_{50}$ value of the inhibitor 2,4-PDCA was carried out in the similar way, except for fixing the enzyme concentration at $800 \mathrm{nM}$ and the reaction duration at 30 minutes. Various amounts of the inhibitor was spiked to the reaction solution with the final concentration reaching $53.3 \mu \mathrm{M}$. The $\mathrm{IC}_{50}$ value was found by fitting the plot of sensor fluorescence vs. inhibitor concentration to the exponential decay equation using Origin 8.0:

$$
\left(\mathrm{F}_{0}-\mathrm{F}\right) / \mathrm{A}=\exp \left(-\mathrm{x} / \mathrm{t}_{1}\right)
$$

The value of $\mathrm{t}_{1}$ was found to be $10.97 \mu \mathrm{M}$, with $\mathrm{R}^{2}=0.9975$ and thus $\mathrm{IC}_{50}=\ln (1 / 2) * \mathrm{t}_{1}=7.4$ $\mu \mathrm{M}$.

\section{Preparation of Liposomes}

Liposomes used to break up the guest aggregation induced by binding with cavitand were prepared from $200 \mu \mathrm{L}$ of $10 \mathrm{mg} / \mathrm{mL}$ POPC in chloroform. The solution was first dried under a nitrogen flow in a clean $2 \mathrm{~mL}$ volume glass bottle; and then $1 \mathrm{~mL}$ of $1 \times \mathrm{PBS}$ was added and the

mixture was allowed to sit on the bench for 15 minutes. Then the solution was vortexed vigorously for 1 minute. The mixture was further sonicated for 2 hours. The obtained liposome was kept at 4 ${ }^{\circ} \mathrm{C}$ before use.

\section{Fluorescence Life Time Measurement}

Time resolved measurements were performed with a $1 \mathrm{kHz}$ Coherent Libra Ti:Sapphire regeneratively amplified laser system and a Hamamatsu C4334 Streakscope with 15 ps time resolution and $2.5 \mathrm{~nm}$ wavelength resolution. A beam splitter sent 50 percent of the $800 \mathrm{~nm}$ fundamental pulse into a frequency doubling BBO crystal to produce the $400 \mathrm{~nm}$ excitation beam. Integrated emission intensity was collected using front face detection with a $400 \mathrm{~nm}$ short pass filter in place before the streak camera. Filters were put in place before the streak camera in order to eliminate stray light. Using Time-Correlated Single Photon Counting (TCSPC), the amount of photons given off as a function of time were recorded. This was then be turned into a plot of natural log of signal versus time, in which the slope is relative to the fluorescence lifetime. 


\section{Surface Tension Measurement}

Surface tension was measured by the Fisher Surface Tensionmat (Fisher Scientific, Inc.) equipped with a platinum ring having a mean circumference of $6.004 \mathrm{~cm}$. The ring and the plastic petri dish $(30 \times 10 \mathrm{~mm})$ used as the solution container were cleaned with DI water three times before use. A stock cavitand 1 solution of $1 \mathrm{mg} / \mathrm{mL}$ was prepared. Aliquots of this stock solution were continuously added to $3 \mathrm{~mL}$ of $1 \times \mathrm{PBS}(\mathrm{pH}=7.4$ ) and mixed well, while the surface tension was recorded after the addition of each aliquot. The surface tension of the cavitand/guest mixture was measured in the same way, with the stock solution being the mixture of $\mathbf{1}$ and $\mathbf{2}$ at a fixed molar ratio of $3: 20$ (stock $[1]=1 \mathrm{mg} / \mathrm{mL})$. 


\section{Supporting Figures}

\section{Dissociation Constant Calculation via Fluorescence Change}

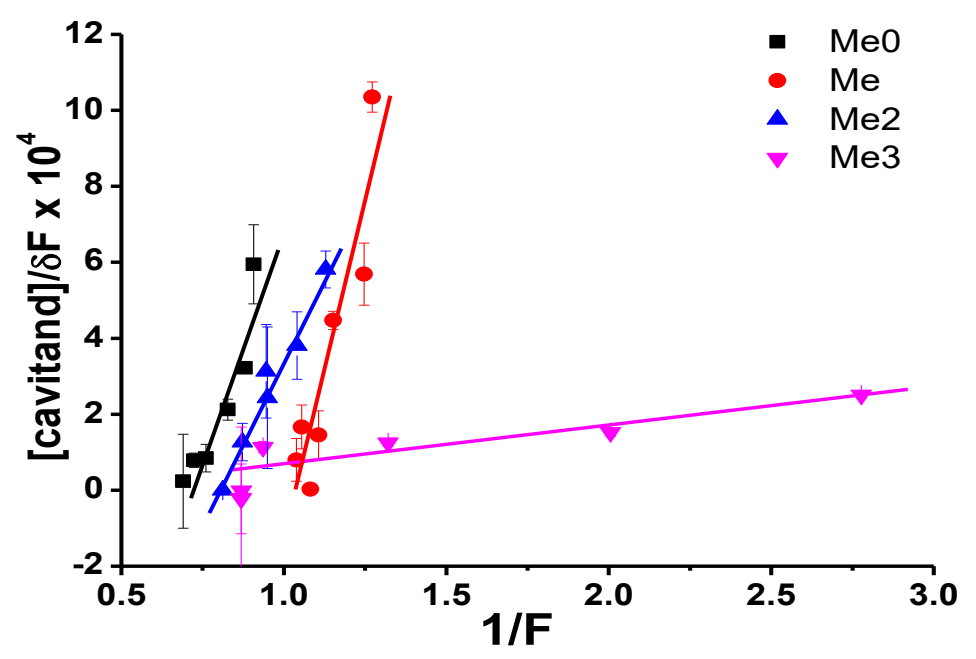

\begin{tabular}{|l|l|}
\hline Guest & $\mathbf{K}_{\mathbf{d}}(\boldsymbol{\mu M})$ \\
\hline Fluorescein (Me0) & $149 \pm 19$ \\
\hline Me (Guest 4) & $406 \pm 263$ \\
\hline Me2 (Guest 3) & $183 \pm 18$ \\
\hline Me3 (Guest 2) & $17 \pm 10$ \\
\hline
\end{tabular}

Figure $\mathbf{S - 1}$. The linear plots for determination of the dissociation constants $\left(\mathrm{K}_{\mathrm{d}}\right)$ for complexes formed between various guest molecules and cavitand. The plot was fitted to:

$$
[\text { cavitand }] / \Delta \mathrm{F}=\mathrm{K}_{\mathrm{d}}(1 / \mathrm{F})+[\text { Guest }]_{0} / \mathrm{F}_{0},
$$

in which $\Delta \mathrm{F}$ was the fluorescence difference measured with $(\mathrm{F})$ or without cavitand $\left(\mathrm{F}_{0}\right)$; and [Guest] $]_{0}$ was the concentration of the guest molecule. The slope of the plot was the $\mathrm{K}_{\mathrm{d}}$. The guest concentration remained at $3 \mu \mathrm{M}$ during the titration with increasing cavitand concentration at 0.10 , $0.50,1,3,5,10,20$, and $50 \mu \mathrm{M}$. Two assumptions were used to obtain the linear relationship between [cavitand] $/ \Delta \mathrm{F}$ and $1 / \mathrm{F}: 1$ ) the binding between the guest and cavitand 1 was at a 1:1 ratio; and 2) the quenching was complete so that any cavitand-bound guest would yield zero fluorescence and $\mathrm{F}$ was proportional to the concentration of the unbound guest. The $\mathrm{K}_{\mathrm{d}}$ values obtained from two independent measurements (each concentration was repeated three time in each measurement, and the results from one of the measurements were shown here) were listed in the table. 


\section{NMR Analysis}

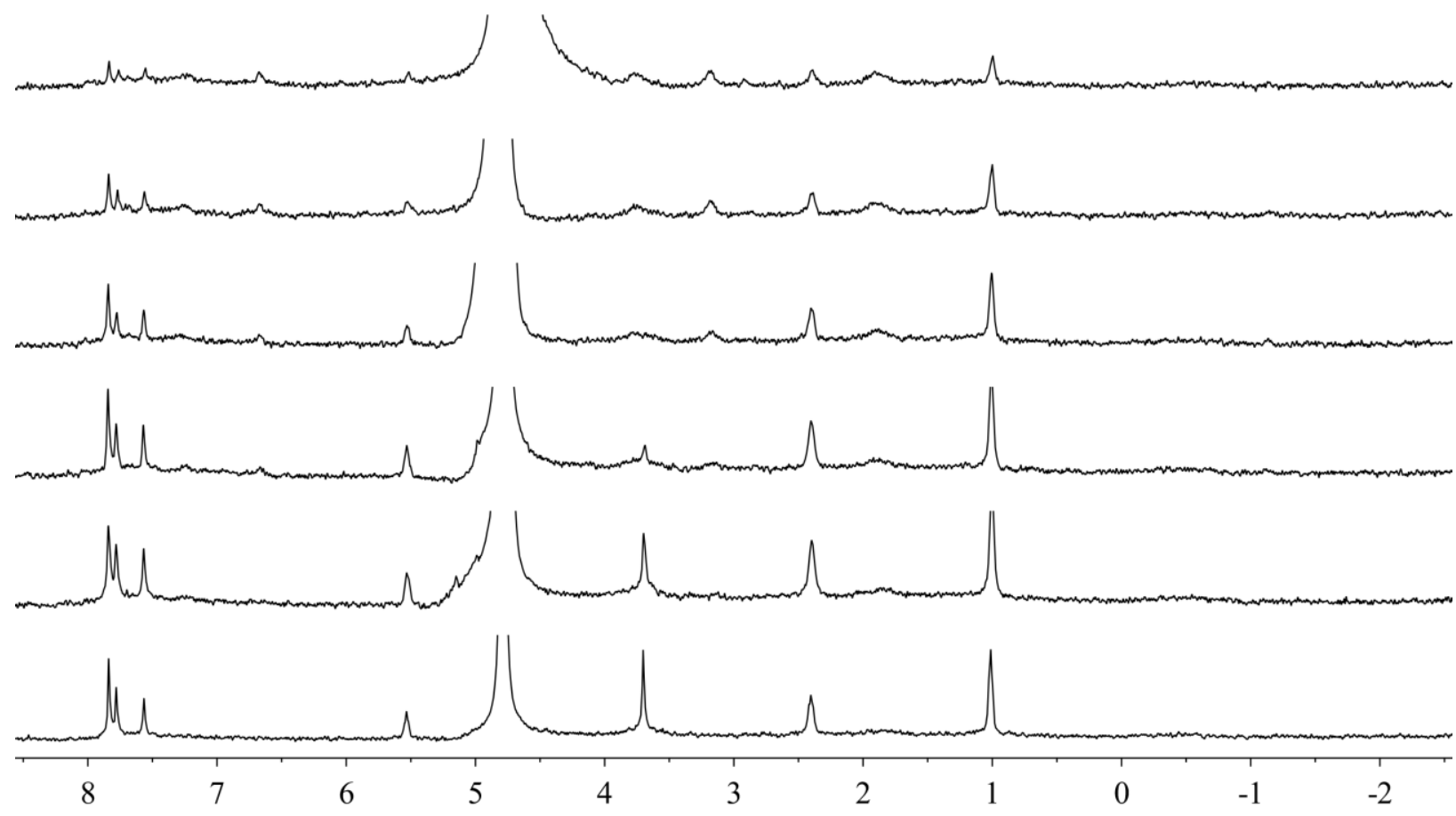

Figure $\mathbf{S}-2 .{ }^{1} \mathrm{H}$ NMR spectra of the titration of trimethylammonium guest 2 into a solution of cavitand $1\left(400 \mathrm{MHz}, 298 \mathrm{~K}, \mathrm{D}_{2} \mathrm{O},[1]=2 \mathrm{mM}\right)$. Bottom spectrum = 1. Other spectra = five sequential additions of 0.2 molar equivalents of $\mathbf{2}$. Proton signals for both $\mathbf{1}$ and $\mathbf{2}$ are lost upon addition of $\mathbf{2}$, indicating the formation of large slow tumbling aggregates, and no free $\mathbf{2}$ is observed (see Fig S5), indicating strong 1:2 association.

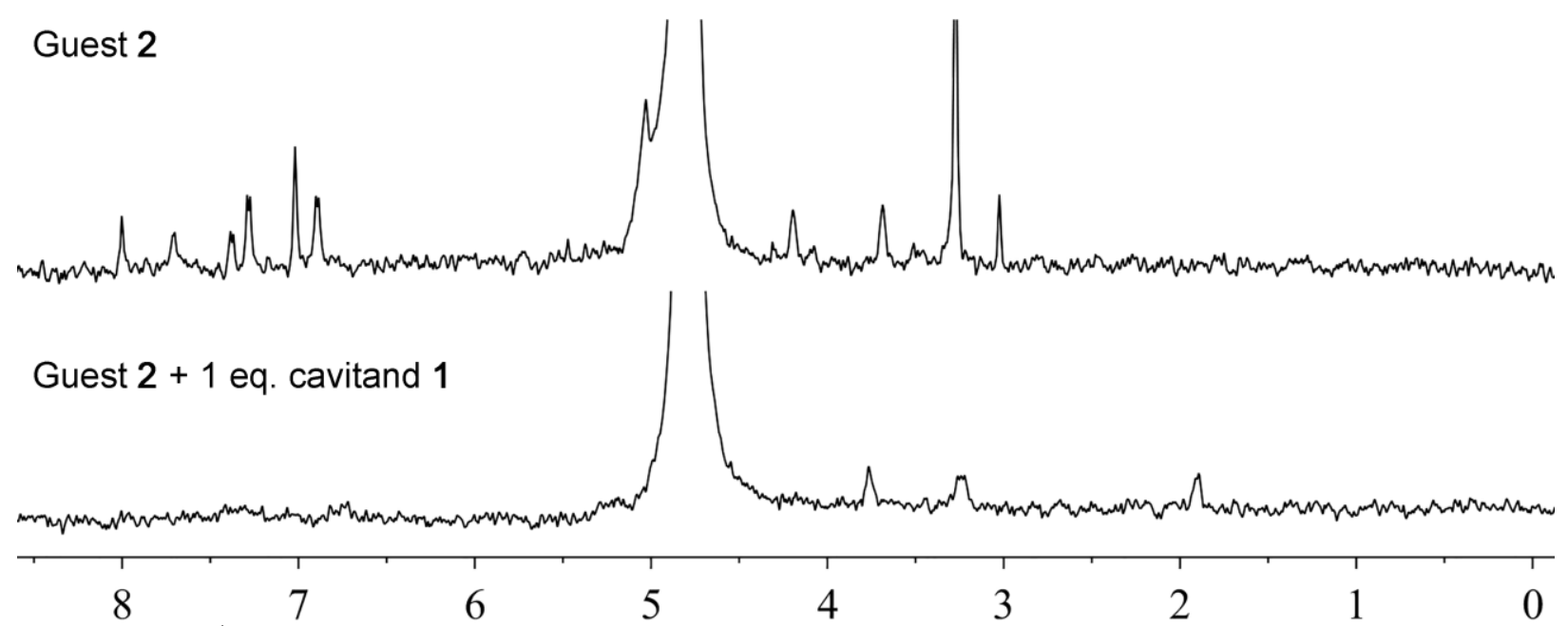

Figure $\boldsymbol{S}$-3. ${ }^{1} \mathrm{H}$ NMR spectra of the addition of cavitand $\mathbf{1}$ into a solution of trimethylammonium guest $2\left(400 \mathrm{MHz}, 298 \mathrm{~K}, \mathrm{D}_{2} \mathrm{O},[\mathbf{2}]=0.25 \mathrm{mM}\right)$. Proton signals for both 1 and 2 are lost upon addition of $\mathbf{2}$, indicating the formation of large slow tumbling aggregates. 

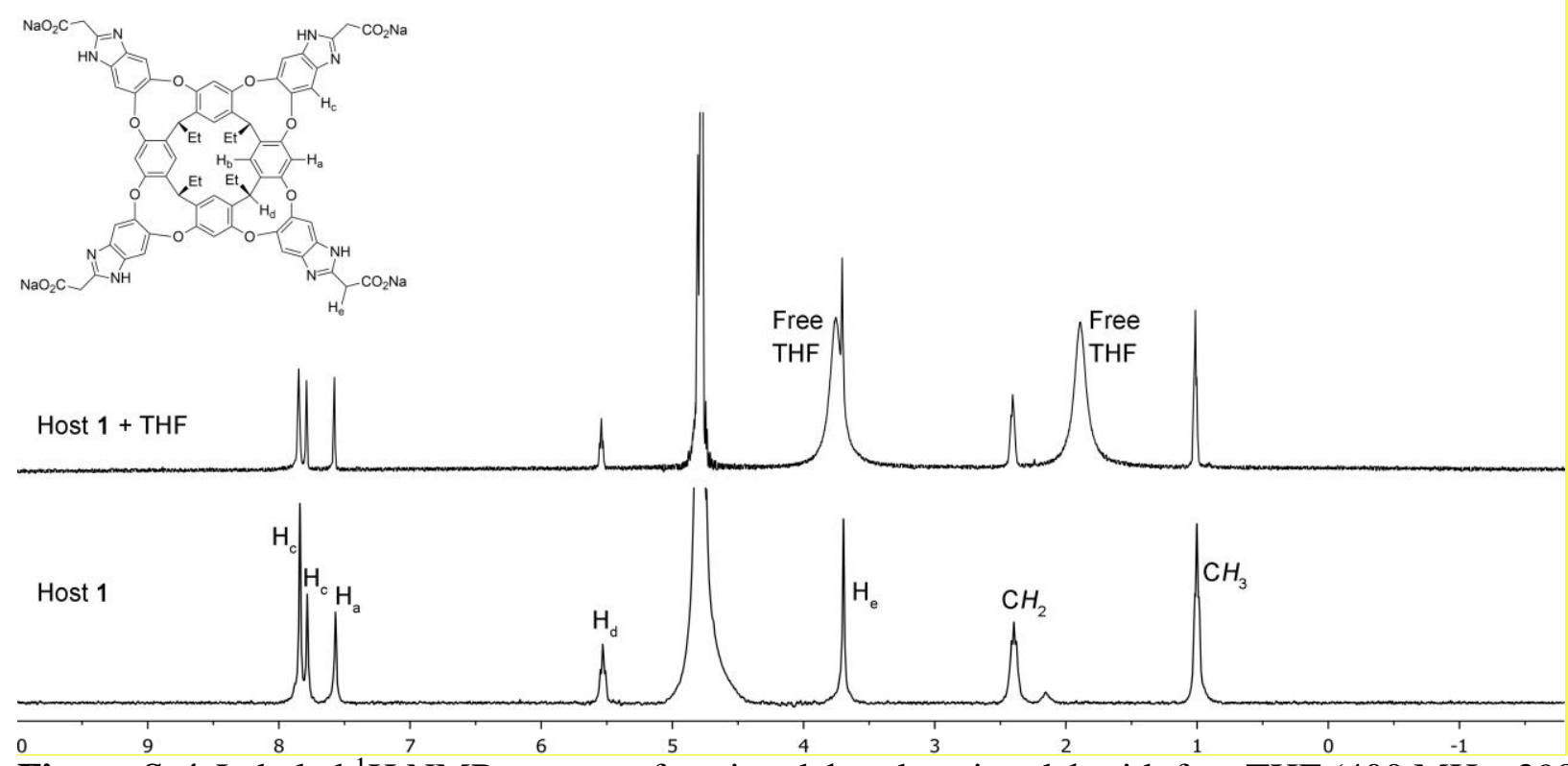

Figure $S$-4. Labeled ${ }^{1} \mathrm{H}$ NMR spectra of cavitand $\mathbf{1}$ and cavitand $\mathbf{1}$ with free THF (400 MHz, 298 $\left.\mathrm{K}, \mathrm{D}_{2} \mathrm{O},[1]=2 \mathrm{mM}\right)$.

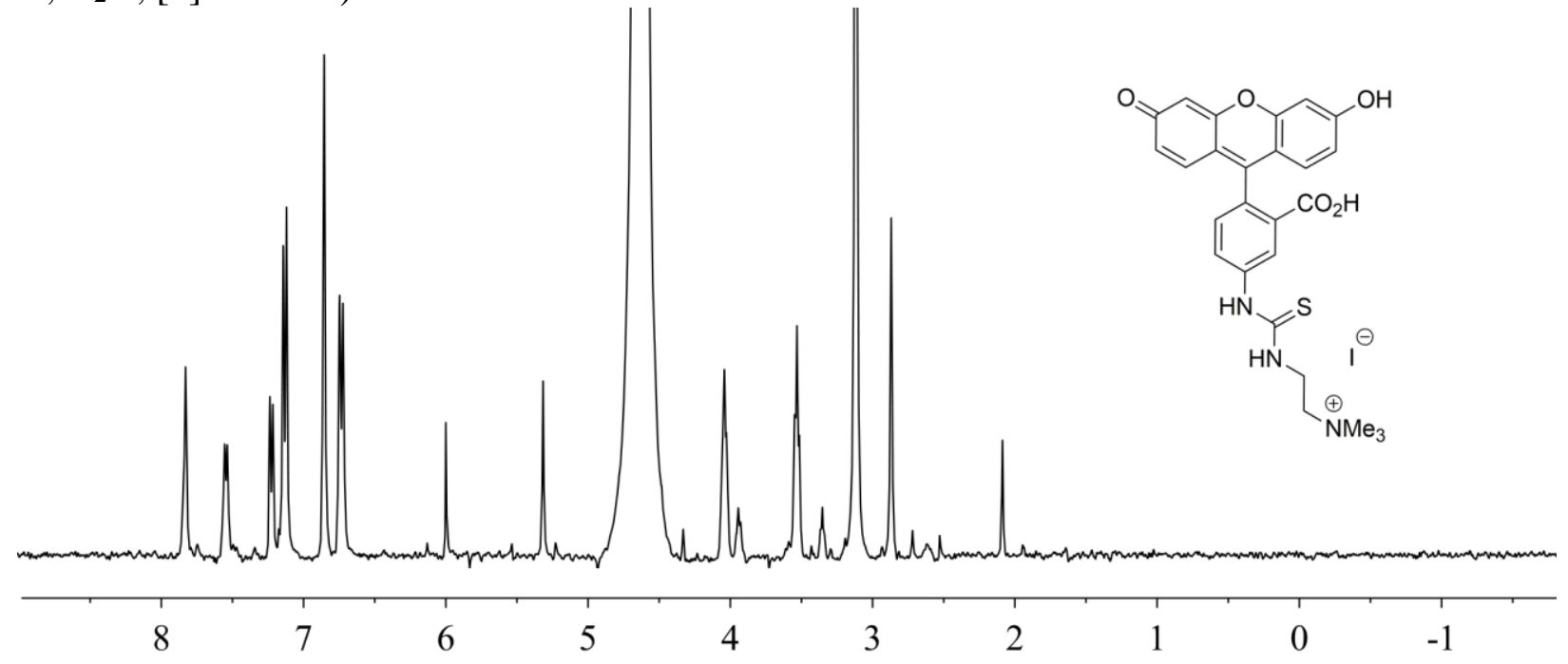

Figure $S-5 .{ }^{1} \mathrm{H}$ NMR spectrum of guest $2\left(400 \mathrm{MHz}, 298 \mathrm{~K}, \mathrm{D}_{2} \mathrm{O},[\mathbf{1}]=1 \mathrm{mM}\right)$ 


\section{Surface Tension Measurement}

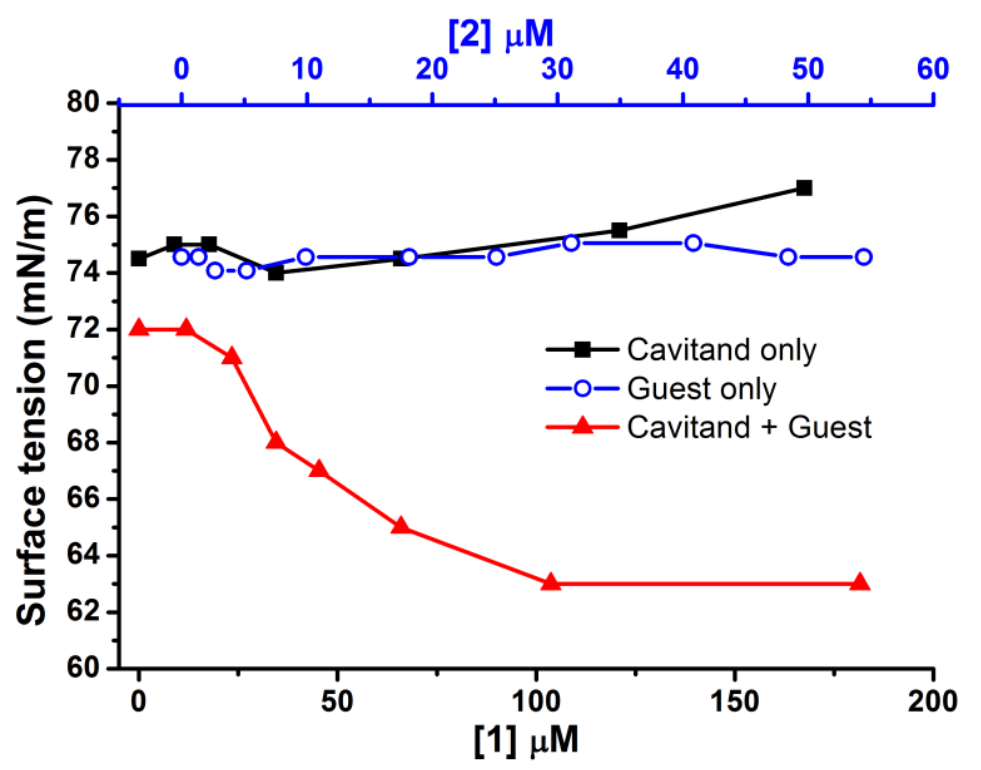

Figure S-6. The surface tension decreased significantly with increasing [1] while keeping the molar ratio of $2: 1$ at $3: 20$, indicating the "surfactant-like" behavior of the $2 \cdot 1$ complex. ${ }^{3}$ However, the surface tension did not change if only the cavitand or the guest was present. The surface tension of the complex solution reached the lowest point at $[\mathbf{1}]=100 \mu \mathrm{M}$, indicating formation of the micelle-like structure decreased the number of complex molecules at the air-solution interface. This phenomenon supported the hypothesis of aggregate formation upon guest-cavitand interaction.

\section{Optical Measurements}

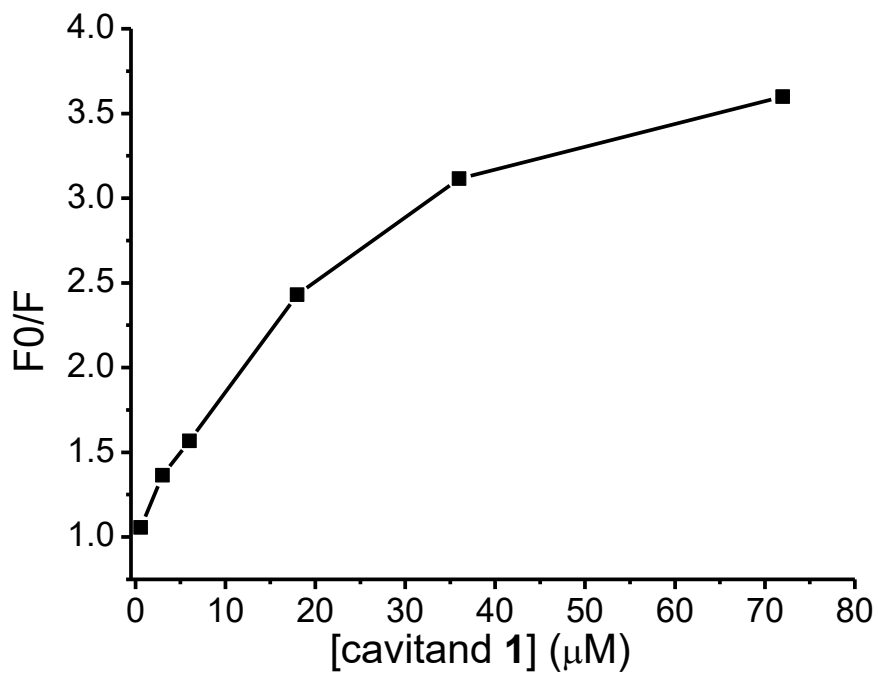

Figure $S$-7. The fluorescence decreased with increasing both concentrations of guest 2 and cavitand 1 while keeping the guest : cavitand ratio at $1: 6$. 


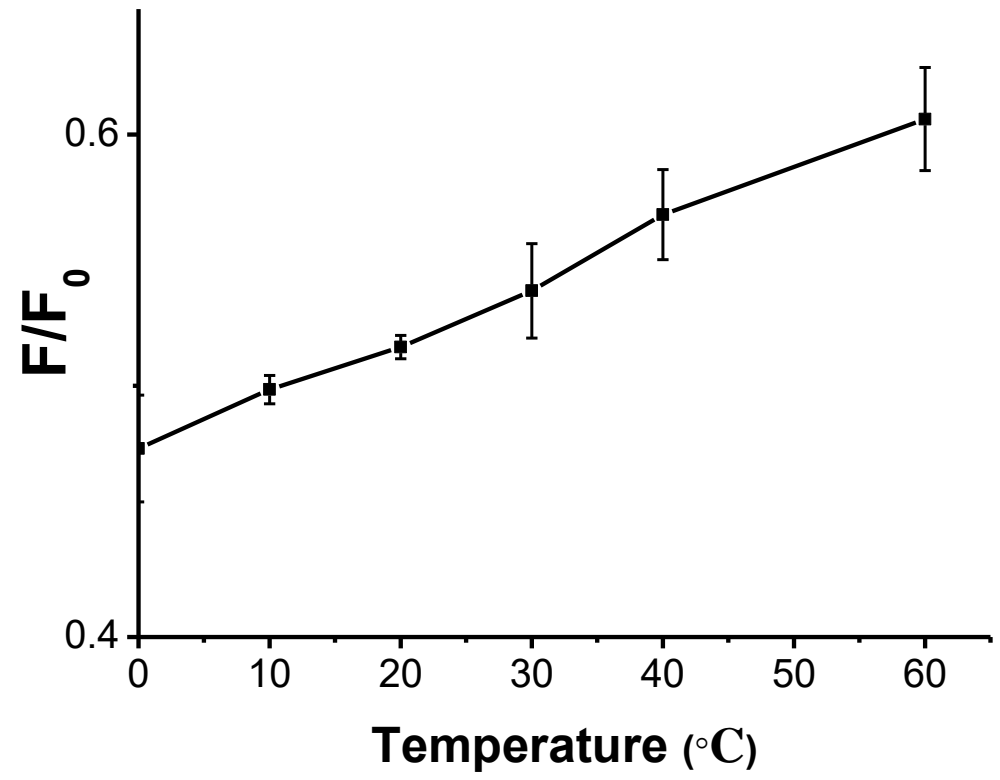

Figure $S$-8. Temperature effect on quenching. The sensor solution contained $3 \mu \mathrm{M}$ guest 2 (30 $\mu \mathrm{M}$ and $20 \mu \mathrm{M}$ cavitand $\mathbf{1}$ in $1 \times \mathrm{PBS}$, and the solution was cooled or heated to different temperatures. Higher the temperature was, less quenching was observed.

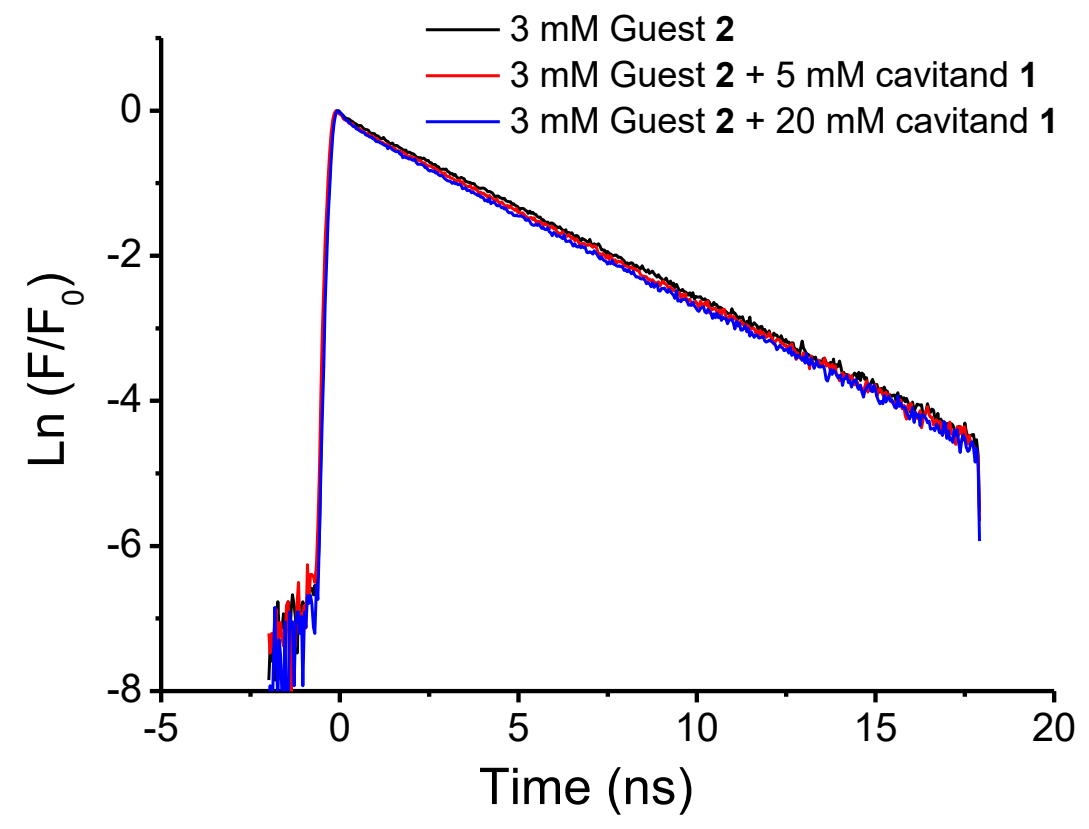

Figure S-9. Fluorescence lifetime measurement for Guest 2 with or without the presence of cavitand 1. 


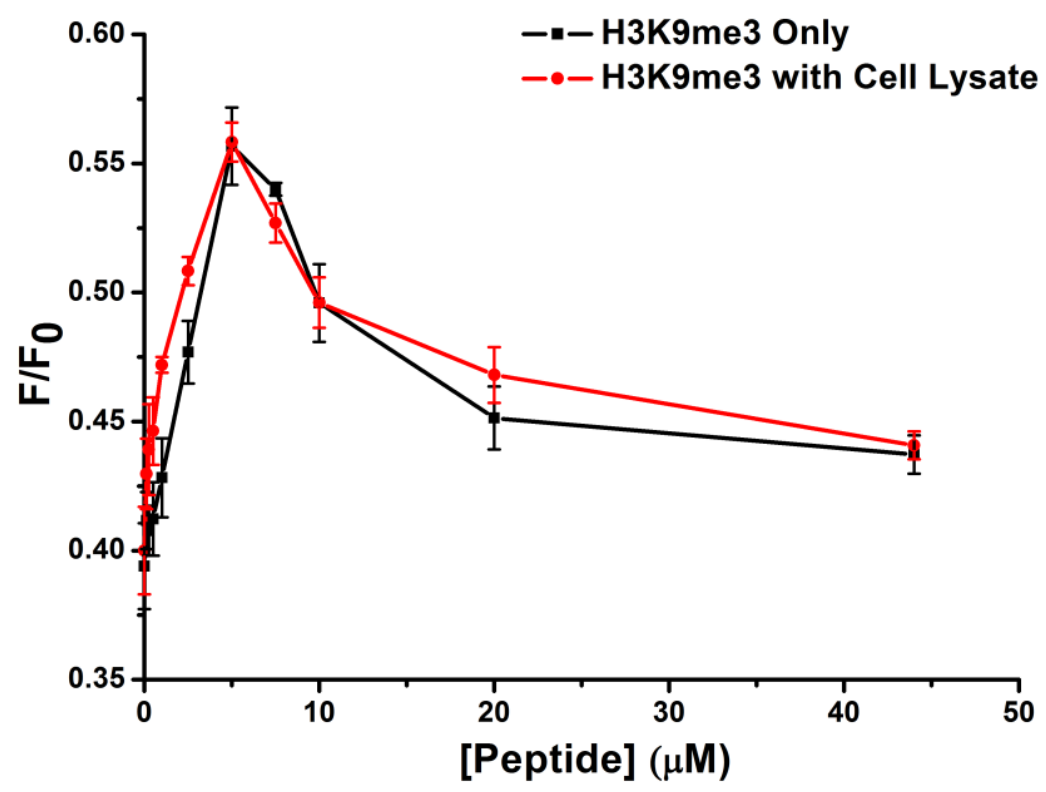

Figure S-10. Fluorescence recovery induced by adding the trimethylated peptide $\left(\mathrm{H}_{3} \mathrm{~K} 9 \mathrm{Me} 3\right)$ to

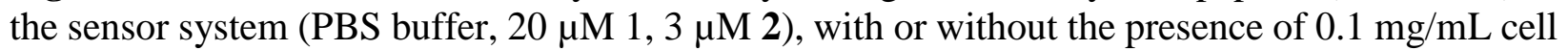
lysate digest prepared from Mouse Raw 264.7 macrophages. 
Enzyme Assays

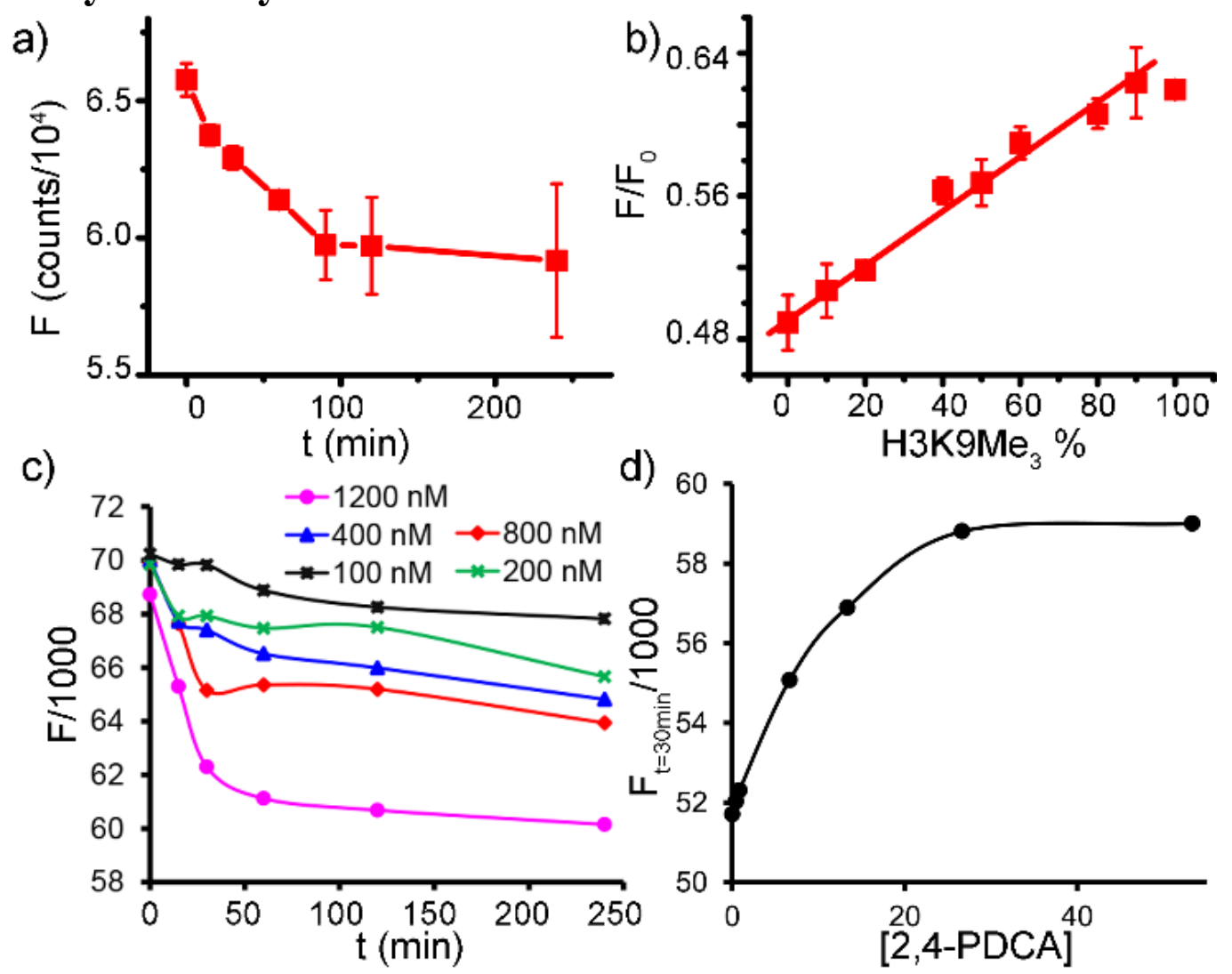

Figure S-11. a) Sensor ( $20 \mu \mathrm{M} \mathrm{1,} 3 \mu \mathrm{M}$ 2) fluorescence in the presence of JMJD2E (400 nM); b) sensor response is dependent on methylation ratio; c) effect of varying [JMJD2E]; d) JMJD2E assay in the presence of PDCA inhibitor.

\section{Liposome Experiment}

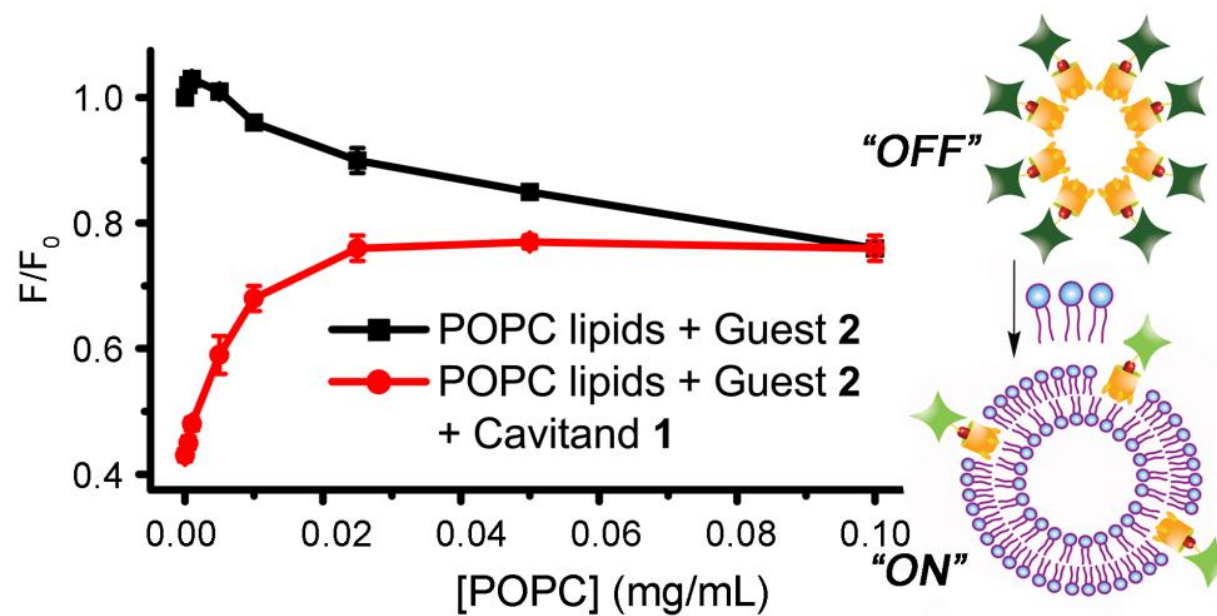

Figure S-12. Effect of POPC lipid vesicle concentration on the fluorescence of the $\mathbf{1} \cdot \mathbf{2}$ host:guest complex $(20 \mu \mathrm{M} 1,3 \mu \mathrm{M} 2)$. 


\section{References}

1) Biros, S. M.; Ullrich, E. C.; Hof, F.; Trembleau, L.; Rebek, J., Jr. J. Am. Chem. Soc. 2004, 126, 2870-2876.

2) Liu, Y.; Liao, P.; Cheng, Q.; Hooley, R.J. J. Am. Chem. Soc. 2010, 132, 10383.

3) Rosen, M. J. In Surfactants and Interfacial Phenomena, 2nd ed.; Wiley-Interscience: New York, 1989; p 3. 